An autoethnographic account of a cycling charity challenge event: exploring manifest and latent aspects of the experience.

\author{
Alexandra Coghlan \\ International Centre for Ecotourism Research \\ Griffith University, \\ Gold Coast, Qld.
}

Email: A.coghlan@ griffith.edu.au

Phone: $+61(0) 755527368$

Fax : +61(0)7 55528895 .

To cite this article: Alexandra Coghlan (2012): An autoethnographic account of a cycling charity challenge event: Exploring manifest and latent aspects of the experience, Journal of Sport \& Tourism,

OI:10.1080/14775085.2012.729899 


\title{
An autoethnographic account of a cycling charity challenge event: exploring manifest and latent aspects of the experience.
}

\begin{abstract}
:
Charity challenges are an increasingly popular form of alternative tourism, drawing upon charity events, sports and tourism. This study adopts a thematic/analytic autoethnographic approach to explore some of the themes present in the author's experience of a three day cycling charity challenge event in Queensland, Australia. The aim of the research was specifically to explore both the manifest and latent aspects of the experience using diary entries created during the event. Using an emic, inductive approach, eight manifest themes were identified that could be analysed with respect to the broader literature in related fields of tourism, sport and charity events. Another two more latent themes also appeared in the analysis, that have previously not been examined within this context. The first was the notion of creative expression as a result of fundraising for the event, and the second was related overcoming a fear of cycling in traffic. The findings raise questions about how we might understand the unspoken facets of the tourism experience. Topics such as fear and anxiety are not easy to discuss with external researchers, or to capture in their entirety through prescriptive research methods, such as surveys, structured or semi-structured interviews. This paper provides insights into one event that occurs at the boundaries of cycling tourism, sports and charity events, whilst advocating for an understanding of the nuances that permeate participants' experiences of such events. Failure to recognize and acknowledge these nuances may lead to misleading managerial suggestions, poor policy design, and unsuccessful new initiatives.
\end{abstract}

Key words: charity challenge, autoethnography, cycling tourism.

\section{INTRODUCTION}

This paper explores the issue of manifest and latent aspects of the experience of participating in a cycling charity challenge event. To access both the manifest and latent issues, this paper adopts an autoethnographic approach, drawing on a qualitative study of a personal experience to transcend the narration of the self and "engage in cultural analysis and interpretation" (Tolich, 2010, p.1606). The aims of the paper are to draw out some of the complexities 
around understanding how individual's perceive and interpret their own experiences, and showcase a particular method to engage with personal experiences, both in creating new knowledge and as a way of exploring these issues for future studies. To achieve this aim, this paper covers the following topics: first, it considers some of the issues around understanding tourism experiences. Second, it reviews autoethnography as a data collection method. Next, it introduces the notion of (cycling) charity challenges (i.e. a combination of charity, sport and travel) and the research context, before moving on to aims, methods and results, including the person context for the research. Last, it provides the local socio-cultural context to frame the research findings surrounding the latent aspects of the experience and discusses their significance.

\subsection{Understanding (sport) tourism experiences:}

Within the tourism literature, a number of tourism scholars have criticised a research bias toward positivism, or postpositivism that reflects the dominion of business and management approaches aimed at producing, managing and selling the tourism product (e.g. Pritchard, Morgan \& Ateljevic, 2011; Belhassen \& Caton, 2009; Ren, Pritchard \& Morgan, 2010). Within sports tourism, scholars such as Gibson (2004), Holloway, Brown and Shipway (2010) and Weed (2006) have also identified the lack of a diversity of methodologies. For instance, Weed's (2006) review of sport tourism research between 2000 and 2004 indicated that qualitative studies make up only $29 \%$ of studies in this area.

The result of this hegemony of positivist studies is that tourism research omits large parts of the "canvas of tourism truth" such as emotions, aesthetics and values, which all contribute to how individuals make meaning out of their experience, are largely uncharted areas (Tribe, 2006). Of particular relevance to this study is Getz's (2008) remark that there has been little research attention paid to event tourism experiences, whilst the meanings attached to travel and event combinations has not been fully explored. He argues that there is clearly a need to look deeper into the experiential realm through anthropological methods like participant observation, phenomenology, and to use experiential sampling as employed in leisure studies.

There appears to be, therefore, growing calls for a local-emergent knowledge that assists in understanding tourists' inner worlds (Jamal \& Hollinshead, 2001) and participant-driven reflective methodologies, and researchers learning through active engagement "to transform 
our way of seeing, being, doing, and relating in tourism worlds" (Pritchard et al., 2011, p. 11). Again, Getz (2008) reminds us to adopt a holistic approach in understanding experiences, by specifically addressing three inter-related dimensions; (i) the conative dimension (what people are doing, their behaviour); (ii) the affective dimension (their emotions, moods or attitudes) and (iii) the cognitive dimension (awareness, perception, understanding). In a sports tourism context, Robinson and Gammon (2004) drew attention to the difficulties in understanding the drivers of an experience, using Iso-Ahola's (1980, cited in Robinson \& Gammon, 2004) example of the iceberg, where the tip of the iceberg represents expressed motives, whilst the overwhelming majority of the iceberg remains hidden below the waterline. They argue that the latter may be so specific to the "individual's own biographies and in any case are so deep rooted as to be practically imperceptible by those experiencing them" (p.222).

Similar concerns were highlighted by Holbrook and Hirschman (1982) in their seminal paper on understanding experiences in the service industries. Of particular relevance to this study are the knowledge structures that Freudians call "manifest" and "latent" content which Holbrook and Hirschman (1982) argue are important when adopting an experiential perspective of services. They describe "manifest" content as those "those ideas that are accessible to introspection and therefore form the substance of conscious thought patterns" whilst "latent" content is "more subconscious and private in nature [...] such material often masks embarrassing or socially sensitive ideas and perceptions" (p.136). They point out that this "latent" content does not appear in verbal reports either because it has been repressed or because its anxiety provoking nature encourages disguise at a subconscious level, but that they can be "retrieved and reported if sufficiently indirect methods are used to overcome sensitivity barriers" (p.136).

The observations made by Holbrook and Hirschman (1982) concerning the latent content within knowledge structures may be particularly relevant for certain aspects of cycling tourism experience. Broadly speaking, cyclists are associated with negative stereotypes (Leonard, Spotswood \& Tapp, 2011; Rissel et al., 2010); cycling has become a marginalised activity associated with poor social representations, where the cyclist is "othered, stigmatised and stereotyped" (Dickinson \& Robbins, 2009, p.81). In a similar vein, Horton (2007, p.134) argues that those "on the margins of cycling have to negotiate their representations of cyclists and with the possibility of [...] becoming a cyclist". This is all the more pertinent in an 
Australian context where cycling rates are still relatively low, but cyclists are overrepresented in traffic incidents and there "is a low tolerance for cyclist mistakes" (Garrad, Greaves \& Ellison, 2010). Rissel et al.'s (2010) study of cyclists in the Australian media found twice as many negative "framings" than positive "framings"; cyclists were often portrayed as "irresponsible lawbreakers", "pariahs" and "dangerous to others". If marginalisation and stereotyping is present, local-emergent knowledge and participant-driven reflective methods are useful to addresses crises of representation, whereby "turning the ethnographic gaze in on itself, autoethnography allows the marginalized voice to speak for itself” (Boylorn, 2008, p.414).

This paper therefore adopts an autoethnographic approach to studying a cycling charity challenge event, using a phenomenological approach focused on the "experiencing person" in a way that documents his or her social reality (Getz, 2008). This involves an inductive, emic approach which is uniquely placed to access the inner world of event participants. Building upon the autoethnographic approach, this paper seeks to uncover what lies below the iceberg's waterline (c.f. Iso-Ahola, 1980), and explores how 'personal biographies' intersect with social structures of the sporting activity", aspects of the experience which may not be apparent using a more scientific approach (Shipway, 2010, p.49). In addressing the "latent" experiential content that is not readily observable, combined with participants' personal biographies, I suggest that this approach may be able to draw out aspects of the experience that less readily available through other qualitative techniques, and certainly not accessible through quantitative techniques. The following section will explore the use of autoethnography in tourism and sports literature.

\subsection{Autoethnography as a research technique}

The use of autoethnography has emerged within the traditions of ethnography. It is therefore useful to review some of the fundamentals of ethnography before moving on to autoethnography. Shipway and Jones (2007), Shipway (2010) and Holloway et al. (2010) provide excellent overviews of the use of ethnography in sport tourism. It is a form of naturalist enquiry, that draws upon participant observation, interviews and an examination of documents that enables researchers to explore the structures and meanings of an experience within a particular cultural context. It adopts an emic, insider perspective of the social setting under study, and requires the researchers to become immersed in the field in order to 
understand the perspectives of the members of the social group under scrutiny. Holloway et al. (2010) remind us that the ethnographer must not impose his or her view on participants (as often occurs through questionnaires or interviews) and indeed, ethnographers are encouraged to adopt an inductive approach that does not start with a theory, but with curiosity instead (Shipway, 2010).

Autoethnography takes the principles of ethnography and applies them to the researcher/author as the study subject. It is a research technique that examines the dialectics of "subjectivity and culture, in general entails the detailed analysis of researcher(s) qua member(s) of a social group" (Allen-Collinson \& Hockey, 2010). It has been described as a genre of research and writing challenging views of silent authorship, and explicitly writes the author into the research, adopting a local-emergent approach to knowledge generation (Deetz, 1996). It responds to a number of calls within tourism research for "a method of investigation that acknowledges the researcher's complicity in knowledge building” (Swain, 2004, p.116), “explicit examinations of researchers' embodied characteristics” (Phillimore \& Goodson, 2004, p.16), "narratives which locate the situated particularity of the 'body' and 'emotion' in tourism" (Jamal \& Hollinshead, 2001), and those aspects of "tourism truth" that remain latent, and draw forth the subjective meaning-making that goes with the tourist experience (Tribe, 2006).

The autoethnographic approach remains relatively uncommon within tourism studies (with some exceptions, e.g. Botterill; 2003; Jennings, Kachel, Kensbock \& Smith, 2009; Muzaini, 2006; Noy, 2007; Scarles, 2010), although it is accepted within disciplines that feature a strong embodied and/or subjective component, and has been adopted by number of researchers interested in sport experiences (e.g. Allen-Collinson \& Hockey, 2010; Collinson, 2008; Fleming \& Fullagar, 2007; Holt, 2003; Sparkes, 2000, 2002). The technique draws heavily on the narrative and the literary turn (i.e. a shift from an observational and empirical methodology to a communicative and dialogical epistemology) in qualitative social sciences, where writing becomes a way of knowing (Coffey, 1999; Collinson, 2008; Richardson, 1994; Sparkes, 2000). In particular, the technique has been endorsed as a useful tool for investigating changing ideas about the self and identity (Sparkes, 2002). Where it has been adopted, it recognisable as a text that may feature dialogue, emotions and self-consciousness, and of course the use of the first person within the manuscript (Holt, 2003). 
This approach, however, is not without its critics, who question the validity and generalizability of the findings, and may consider the autoethnographic approach to be selfindulgent, introspective, narcissistic and individualized (Coffey, 1999). Proponents of this methodology (and to some extent, qualitative research more broadly) therefore suggest other measures of evaluating autoethnographic research. Sparkes (2000) suggests that criteria such as authenticity, fidelity, evocation, congruence, resonance and aesthetic appeal may provide more useful evaluative measures. Richardson (1994) proposes similar measures, with the added notion of substantive contribution: 1) does the piece contribute to our understanding of social life, and impactfullness; and, 2) does the piece generate new questions or move the reader to action?

With regard to these criteria, Ellis (2004) emphasised the need for autoethnographers to "find their voice" which may range from largely ethnographic approaches to much more literary approaches. Personal accounts and reflections may become woven into the analysis, and/or the author may decide to add another layer of analysis and theorise about the story from a broader perspective. For instance, in the latter case, autoethnographers may apply a thematic analysis to their own narrative, by treating their story as data, and using analysis to derive themes that "illuminate the content and hold within or across stories" (Ellis, 2004, p.196). In the latter case, Ellis (2004) argued that the emphasis shifts to the abstract analysis, rather than the story itself.

The account provided here draws on thematic analysis and aligns itself with what Anderson (2006) calls analytic autoethnography. Anderson (2006) ascribes five key features to analytic autoethnography, which are (i) complete member researcher (the researcher is fully integrated into the social world under study), (ii) analytic reflexivity, (iii) narrative visibility of the researcher's self, (iv) dialogue with informants beyond the self and (v) a commitment to theoretical analysis. It also borrows from narrative analysis techniques, that use first person accounts of experiences which are told in story form (Merriam, 2002). In the study, I therefore adopt a dual role of participant and analyst, and the final report blends personal account, narrative analysis and (auto)ethnography with its inherent socio-cultural interpretation of the experiences.

1.3. Charity challenges and cycling tourism. 
Charity challenges are a relatively new sub-sector within the general area of alternative tourism. Combining activities such as cycling (or hiking) with charity events has become increasingly popular, and the addition of a touring/travel component has led to the development of charity challenges. Goodwin, Eckhardt and McCombes (2009) describe the sport challenge as an opportunity for people to take on the challenge to raise money for a favourite charity. They offer participants "the experience of travel, the experience of a lifetime, with fundraising. A personal experience of travel and challenge combined with an altruistic purpose" (Goodwin et al., 2009, p.66). Lyons (2007) and Lyons and Wearing (2008) describe this form of travel as opportunities that "blend the voluntary act of fund-raising with the more hedonic pleasures of a packaged adventure tour" (p.151). In most cases, the charity promotes a pre-scheduled event, chooses the level of challenge and thrill, and/or may specifically tie the challenge to the charitable purpose (as will be presented in this case). Examples include long-distance, multi-day cycling, hiking, canoe/kayaking events.

Linking charity fundraising with cycling events appears to particularly popular, not least within Australia (e.g. Brisbane's Ride for Life, South Australia's Ride to Cure Diabetes, Victoria's Ride4Epilepsy). When event participation or attendance includes overnight travel away from home, Lamont (2009) suggests that these events be included in a definition of cycling tourism in Australia as "participation in cycling may include attendance at events organised for commercial gain and/or charity (competitive and non-competitive)” (p.20). The rise of cycling charity challenge events is most likely linked to the increase in cycling tourism. This is a growing area of recreation and leisure in its own right, as well as of academic interest (Lamont, 2009). Cycling tourism is believed to have the potential to provide a range of economic, social and environmental benefits, particularly in regional areas (Faulks, Ritchie \& Fluker, 2007; Ritchie, 1998).

Despite the emerging focus on cycling tourism, a number of authors working in the field have decried the lack of demand-side studies in the area (e.g. Faulks, Ritchie, Brown \& Beeton, 2008; Ritchie, 1998; Ritchie, Tkacznski \& Faulks, 2010). Instead, much of the work has focused on specific cycling initiatives and tangible aspects of the cycling experience as they relate to planning, management and use of service provisions, often as part of an agenda to increase cycling patronage (Dickinson \& Robbins, 2009). Meanwhile, Ritchie et al. (2010) specifically draw attention to the heterogeneity of the cycling tourism market, arguing that 
this sector represents a wide variety of individuals with different needs and motivations, and ultimately different experiences.

To date, almost no research has been carried out on events that fall at the boundaries of tourism, charity and sport. To the author's knowledge, the only similar study was by Berger, Greenspan and Kohn (2007) who focused on Jewish identity re-creation through participation in a five-day cycle ride from Israel's Golan Heights to Jerusalem to benefit the Alyn Paediatric Hospital in Jerusalem. Their study therefore was more concerned with a sense of communitas then with the private and unique experiences of individuals that may have differed from the group's sense of purpose around the ride. The study presented here also investigates a multi-day cycle ride designed to benefit a local hospital, the Cairns Cardiac Challenge, but specifically targets both the manifest and the latent aspects of the experience that have not been captured in earlier studies. It uses an autoethnographic approach thereby adding to the body of literature in this area both in content and in methodological approach to the study of charity challenges. The research context, including the researcher's personal situatedness is presented next.

1.4.The research context and researcher situatedness.

As part of the autoethnographic approach, it is pertinent that I present my personal biography as it relates to this study. In May 2009, I experienced any cyclist's nightmare: a collision with two tonnes of oncoming transit vehicle. Returning from my early morning ride, a van turned across the highway - and into my direct path - without giving way. Although the witness reports described a serious, frightening incident, I escaped with minor injuries including some slight scarring on my face from the shattered windscreen and a damaged kneecap. My confidence, however, had taken a major knock. At that time cycling was my main mode of transport and my primary form of exercise, and I decided to look for new ways to rebuild my confidence and my fitness. The Cairns to Cooktown Cardiac Challenge presented itself as an opportunity do to just that.

This charity challenge involves a three day tour of the local region, $335 \mathrm{~km}$ of sealed road from Cairns to Cooktown. It is a form of sport tourism according to Standeven and DeKnop (1999) definition sport tourism as active "involvement in sporting activity, participated in casually or in an organised way for non-commercial or business/commercially reasons, that 
necessitate travel from home and work locality" (p.39). The challenge was first set up in 2007 and has grown from 125 cyclists in its first year to 300 cyclists in 2011. The itinerary takes cyclists up two ranges as part of the challenge (Kuranda and Desailey ranges). Cyclists travel in packs of 10-12 cyclists, each rider having different experience and fitness levels. The riders are accompanied by army support vehicles, volunteers to care for the riders, two first aid vehicles, one for the riders and one for their bicycles, and an entourage of supporters, friends and relatives. Participants are required to pay a registration fee of $\$ 250$, and to raise a further $\$ 300$ for the charity recipient, the Far North Queensland Hospital Foundation. So far nearly AU\$1,000,000 have been raised for the cardiac unit at the local Cairns hospital charity through this charity challenge.

The Cardiac Challenge is a form of regional, small-scale event sport tourism. Chen (2006) and Getz (2008) argue that these forms of tourism have received only limited attention when considering characteristics of event sport tourists and their behaviours associated with smallscale event sport tourism, despite the increased popularity of such events during the last several decades. Thus, this research is also aiming to fill a knowledge gap in this area.

\section{AIMS AND METHODOLOGY:}

The main aims of the data collection and analysis were to access the private meanings created through participating in a charity challenge and understand these meanings within existing scholarly works and the specific social context of the event. The research adopted an emic approach, focussing on an insider perspective of the social setting under study, and adopts an inductive approach that does not start with a theory, but relies on analytic autoethnography as described above (Anderson, 2006).

To carry out an analytic autoethnography, I adopted the role of complete member researcher and became fully integrated into the social world under study, by participating in the Cardiac Challenge from start to finish in September 2010. I employed analytic reflexivity, writing an account of my experiences in a personal diary at the end of every day, during the downtime between arriving at camp and dinner. Thus my personal diary also served as my research diary, and was an extension of my everyday diarising activities. Throughout the process I committed myself to complete honesty and self-reflection within the diary, which translated 
into narrative visibility of the researcher's self within the reported findings. Furthermore, as part of the study of the social and cultural setting of the ride, I engaged in dialogue with informants beyond the self to help me bracket and frame my own experiences. In light of ethical considerations, pseudonyms were used throughout the text, consent was sought wherever possible to publish the material (from participants who are mentioned in the text and from the event organiser), and no information that could harm others was included in the findings and discussion. Finally, the findings demonstrate a commitment to theoretical analysis by placing the emerging themes within the broader literature and theories of leisure, sport and tourism.

The research methods blend analysis of narrative, that is inquiry into stories by a story analyst, with narrative analysis whereby the storyteller inquires with and through the production of story. As part of the analysis of narrative, the first step of the research was to identify themes and patterns within the data, before interpreting these within the context of existing work in this area. Specifically, I was looking for manifest themes, i.e. those themes that appear fairly consistently across the literature in this area, and latent themes, which first, were not readily apparent to me during the ride (a relatively subjective assessment) and second, do not appear to any great extent in the existing literature. Where necessary, other sources of data were used to examine the socio-cultural context of the cycling event, that allowed the results to be interpreted in a broader context. The second step, the narrative analysis blends rhetoric and method, so that the analysis of data entails the production of a meaningful account. This blend of analysis of narrative and narrative analysis is presented next.

\section{FINDINGS:}

In adopting this analytic approach, nine major themes were identified in the diary entries. Of these, seven could be categorised as manifest and appear remarkably consistently across a number of studies of cycling, (sport) tourism and leisure. These were (i) escapism, (ii) socialising, (iii) adventure, (iv) achievement, (v) entitlement/recognition, (vi) companionship, and (vii) special interest. The remaining two themes were (viii) creativity and (ix) fear/anxiety, which to date have received relatively little attention within this field, and arguably represent more latent aspects of the experience. The findings provide insights into 
the complexity and heterogeneity of this type of sport tourism experiences, and raises a number of questions for further study by departing from "static, quantitatively measurable knowledge towards a focus on understanding and expressing that aspect of being which is dynamic experienced and elusive of the positivist researcher" (Jamal \& Hollinshead, 2001, p.67).

\subsection{The manifest aspects of the experience:}

The manifest aspects of the experience are ones that, by and large, we might expect to encounter as part of the experience based on the growing body of knowledge in these areas. They are the ones that have been reported with some consistency across a number of studies in leisure, sport, sport tourism, tourism and charity events. For this reason, a relatively brief overview of these aspects of the experience, along with exemplar diary excerpts or vignettes, are presented in Table 1, along with parallel findings from other studies, and where possible, the theoretical construct that might help explain these findings. The list is by no means exhaustive, and instead intended to demonstrate the consistency with which some aspects of the experience are found across studies, and particularly studies in cycling, sport event tourism, tourism and charity events. These findings are interesting to the extent that they provide support for previous research; their overlaps with previous studies are presented in Table 1. 
Table 1: Diary excerpts illustrating the main themes emerging from the autoethnographic data and their place within the broader literature.

\begin{tabular}{|c|c|c|c|}
\hline Diary entry/data & $\begin{array}{l}\text { Emergent } \\
\text { theme }\end{array}$ & Theoretical construct & $\begin{array}{l}\text { Examples of findings in previous studies } \\
\text { (\& study area) }\end{array}$ \\
\hline $\begin{array}{l}\text { "I love those moments of monotonous road, when you can get lost in } \\
\text { your thoughts and realise that no one is making any demands of you, } \\
\text { and your only job to keep pedaling. How rare is to be fully catered } \\
\text { for, and John (the support vehicle driver) is doing a great job of } \\
\text { watering and feeding us at every stop. You have not a care in the } \\
\text { world beyond following the wheel in front of you, keep pushing those } \\
\text { pedals, and staying hydrated. What complete and utter escapism! I } \\
\text { wish it could last forever." }\end{array}$ & Escapism & $\begin{array}{l}\text { Escapism-seeking } \\
\text { (Iso-Ahola, 1980) }\end{array}$ & $\begin{array}{l}\text { Pearce \& Lee, } 2005 \text { (Tourism) } \\
\text { Dickinson et al., } 2011 \text { (Cycling tourism) } \\
\text { Ritchie et al., } 2010 \text { (Cycling tourism) } \\
\text { Lumsdon, } 2000 \text { (Cycling tourism) }\end{array}$ \\
\hline $\begin{array}{l}\text { "One of the great things about pack riding is that you get the chance } \\
\text { to talk to everyone as you rotate around to the front and back. We } \\
\text { have a good bunch. Jo is the cheeky one, he and his friend are like two } \\
\text { little mischievous imps. Brendan works in a similar field to me, it's } \\
\text { interesting to hear his perspective on things. Justine is full of bluff and } \\
\text { bluster, she is great to keep you going up the hills. And of course, } \\
\text { Sally is organising sing-alongs at the back, keeping us all in good } \\
\text { spirits". }\end{array}$ & Socializing & $\begin{array}{l}\text { Social identity } \\
\text { Theory (Tajfel \& } \\
\text { Turner, 1986). }\end{array}$ & $\begin{array}{l}\text { Snelgrove \& Wood, } 2010 \text { (Charity cycling) } \\
\text { Ritchie et al., } 2010 \text { (Cycling tourism) } \\
\text { Downward \& Lumsdon, } 2001 \text { (Recreational } \\
\text { cycling) } \\
\text { Shipway, } 2010 \text { (Sport event tourism) } \\
\text { Won et al., } 2011 \text { (Charity sport events) }\end{array}$ \\
\hline $\begin{array}{l}\text { "My heart sank when I heard it was Jason who came off his bike } \\
\text { coming down the range today. Talking to him last night it was obvious } \\
\text { he wasn't having a good ride this year. What a way to finish it off! } \\
\text { Apparently, he got away with just a broken finger-amazing } \\
\text { considering he was doing } 80 k m \text { an hour at the time. You always hope } \\
\text { that there will be no serious incidents for the three days that we are } \\
\text { out here, but this goes to show that there is no guarantee" }\end{array}$ & Adventure & $\begin{array}{l}\text { Peak Experiences } \\
\text { (Maslow, 1977) } \\
\text { Edgework (Lyng, } \\
\text { 1990) }\end{array}$ & $\begin{array}{l}\text { Buckley, } 2010 \text { (Adventure tourism) } \\
\text { Faullant et al., } 2011 \text { (Tourism) } \\
\text { Shipway \& Jones, } 2007 \text { (Sport tourism } \\
\text { events) }\end{array}$ \\
\hline
\end{tabular}




\begin{tabular}{|c|c|c|c|}
\hline $\begin{array}{l}\text { "I still can't get over that I made it up Desailey Range this year. Oh } \\
\text { what a feeling! All that hard work in training paid off. I am now one } \\
\text { of 'them', the ones that I admired last year from the bus, as they } \\
\text { stubbornly ground their way up the hill. Next year will be the year that } \\
\text { I make it all the way up Kuranda, and will complete the whole event } \\
\text { from start to finish" }\end{array}$ & $\begin{array}{l}\text { Achieve- } \\
\text { ment }\end{array}$ & $\begin{array}{l}\text { Serious Leisure } \\
\text { (Stebbins, 1982) } \\
\text { Leisure Motivation } \\
\text { Scale (Beard \& } \\
\text { Ragheb, 1983) }\end{array}$ & $\begin{array}{l}\text { Ritchie, } 1998 \text { (Cycling tourism) } \\
\text { Snelgrove \& Wood, } 2010 \text { (Charity cycling) } \\
\text { Shipway \& Jones, } 2007 \text { (Sport tourism } \\
\text { events) }\end{array}$ \\
\hline $\begin{array}{l}\text { "I love our little uniforms, a sea of } 300 \text { riders all wearing the } \\
\text { colourful Cardiac Challenge jerseys. We get to wear them like a } \\
\text { badge of honour. It identifies us as serious riders (although no doubt } \\
\text { pack } 1 \text { would laugh at that) with a community spirit and shows our } \\
\text { commitment to the hard work that went into training and fundraising } \\
\text { before the ride. You always give an extra big smile to riders out on the } \\
\text { road when you see them wearing the jersey." }\end{array}$ & Recognition & $\begin{array}{l}\text { Social identity } \\
\text { Theory } \\
\text { (Tajfel \& Turner, } \\
\text { 1986). }\end{array}$ & $\begin{array}{l}\text { Shipway \& Jones, } 2007 \text { (Sport tourism } \\
\text { events) }\end{array}$ \\
\hline $\begin{array}{l}\text { "Poor Kevin, we all knew how he felt as he trudged the last bit up the } \\
\text { hill, pushing his bike in front of him. He is one of the fit ones in the } \\
\text { pack so it was a surprise when he declared himself "rooted" as he } \\
\text { reached us. What we didn't realise that he had been pushing his } \\
\text { girlfriend (a first-timer) up the hill. A gallant effort to get her up, but } \\
\text { in the end she had to get into the support vehicle. Kevin was the last } \\
\text { up, and when he got there Justine reminded us all to look behind us to } \\
\text { get a sense of exactly what we had achieved". }\end{array}$ & $\begin{array}{l}\text { Companion } \\
\text {-ship }\end{array}$ & $\begin{array}{l}\text { Social identity } \\
\text { Theory } \\
\text { (Tajfel \& Turner, } \\
\text { 1986). }\end{array}$ & $\begin{array}{l}\text { Shipway, } 2010 \text { (Sport event tourism) } \\
\text { Shipway \& Jones, } 2007 \text { (Sport event } \\
\text { tourism) } \\
\text { Getz, } 2008 \text { (Event tourism) } \\
\text { Dickinson et al., } 2011 \text { (Cycling tourism) } \\
\text { Pearce, } 1993 \text { (Charity) }\end{array}$ \\
\hline "I feel like such a dork today, when I realised that another reason why & Involvement & Serious leisure & Ritchie et al. 2010 (Cycling tourism) \\
\hline
\end{tabular}




\begin{tabular}{|l|l|l|}
\hline $\begin{array}{l}\text { I enjoy this ride so much is that it gives me the opportunity to check } \\
\text { out expensive bikes, new gear and accessories, and talk about bike } \\
\text { riding with the more experienced cyclists. I learn so much from the } \\
\text { more experienced riders on cadence and hill riding, gearing and even } \\
\text { how to keep my energy up to last the distance. This isn't something I } \\
\text { get to do at home, it's a bit of an indulgence!" }\end{array}$ & (Stebbins, 1982) \\
\hline
\end{tabular}




\subsection{The latent aspects of the experience:}

As well as those aspects of the experience that echoed previous research into cycling, cycling tourism, sport event tourism, event tourism and charity events, there emerged from the data another two distinct somewhat latent aspects of the experience. I have placed them into the subheading of latent as they were not immediately salient to me (as the participant, study subject, research instrument and analyst!) and appeared to fall within Holbrook and Hirschman's (1982) definition of latent material, being "more subconscious and private in nature". Specifically, the first of these two latent aspects, creativity, was "material [that] often masks embarrassing or socially sensitive ideas and perceptions" (p.136), whilst the second aspect, fear of cycling, was "anxiety provoking [in] nature [which] encourages disguise at a subconscious level" (p.136). Both of these latent aspects are explored here in more detail.

The notion of creativity through participation is starting to emerge within the tourism literature, but remains relatively uncommon as a subject matter in studies of tourism material. On this occasion, it could be considered socially sensitive as it related to the experience of asking others for money. In particular, the reflective process highlighted that, whilst I was relatively confident of being able to cycle $335 \mathrm{~km}$, the issue of raising the minimum AU $\$ 300$ was the greater challenge. Asking for friends, colleagues, family and strangers for financial support did not come easily, and I felt a strong need to get creative in ways to raise the funds in a fun, non-threatening and engaging way.

"I love comparing notes on what people did to raise money. It's amazing the ideas people come up with when you put your mind to it. It's one of the more challenging aspects of the event for me, and it's good to get tips from the newsletters that Glenys sends out on who is doing what. It stretches your mind in a new direction trying to think up ways of raising the money for the trip and reach your target”.

With the exception of the newsletters identifying particularly innovative or creative fundraising endeavours, and an acknowledgement of the event's top team and individual fundraisers, discussions of fundraising activities and experiences were notably absent from the participants' conversations. It is possible that this is linked to Western taboo's surrounding discussions of money. Indeed, Belk and Wallendorf (1990) suggest that "money is considered a private matter that is threatening to discuss since it is aligned with notions of 
self-worth" (p.46). This taboo is also addressed by Klein (1998) specifically within the context of fundraising. She argues that "fundraisers are regarded with the same mixture of admiration, loathing, suspicion, and awe with which we in America regard money itself". Furthermore, whilst it may be extreme to suggest simply paying the minimum donation was "fraudulent", it certainly was not perceived as entering into the spirit of things. The conflicting emotions that surround asking for money and discussing fundraising outcomes were certainly present in my own experience, and may have contributed to the relative absence of fundraising as a topic of discussion during the event.

A way, perhaps, of diffusing the taboo around fundraising was to see it as a creative endeavour, an approach used by practioners and advocates of fundraising (c.f. Smith, 2004). The role of creativity itself (as part of the fundraising process) has not yet been explored in charity challenges, or indeed in sports charity events or volunteer tourism. Gibson and Kong (2005) do refer to individuals' personal desire to engage with the affective, emotive, cathartic dimensions of creative pursuits within the "culture economy". Richards $(2006,2010)$ describes an emergence of creative tourism and particularly creative events, that encourage active involvement and encourage creative potential. He argues that events offer a number of advantages in this area, as they are more flexible than physical infrastructure, whilst offering more "spectacle" and "atmosphere", where people can take an active part in producing the experience. Charity challenges such as this one, that features a strong link with the local community may be one emerging variation of such creative events, and as participants we received continuous encouragement to "get out there and get creative" with our fundraising by the event coordinator.

The final dimension of the experience was perhaps the hardest to draw out. This concerned the fear and anxiety generated from returning to road cycling after my incident in 2009 . The narrative began with a consideration of regaining my fitness and confidence as my own personal motivation for participating in this event. Whilst it may appear obvious that a lack of confidence may represent a certain sense of anxiety, I had not allowed myself to experience the full feelings of fear and anxiety generated by cycling on the road. This is certainly was indicative of material that was "anxiety provoking [in] nature [which] encourages disguise at a subconscious level" but also supported the notion that this material could be "retrieved and reported if sufficiently indirect methods are used to overcome sensitivity barriers" (Holbrook \& Hirschman, 1982, p.136). The following diary extract was written on the second day of the 
event, after I had spent some time in the support vehicle, and had the opportunity to observe the interactions between the packs and the cars as well as the logistics of coordinating the traffic around 300 cyclists.

"I still can't shake the what-ifs. What if her chain had come off when there was oncoming traffic? Would any of us have swerved into it automatically to avoid running over her, or causing a pile up for those behind? What if a car (or even worse a truck) misjudges their overtaking? What's he going to do? Swerve into the cyclists or drive off the [other side of] road to avoid a collision? Worse still, what if one of those cranky truck drivers who spend hours abusing us on the VHF radios gets REALLY fed up with overtaking pack after pack of cyclists hogging the lane, and decides to show us who really owns these roads? I am always going to be this paranoid on the bike? I don't remember ever having these feelings on other long distance rides, even though I was on my own and (realistically) way more vulnerable. What's it going to take to get my confidence back up??

Whilst a fear component has been recognised in the cycling literature (for example Dickinson \& Robbins, 2009; Horton, 2007; Jacobsen, 2003), it is not widely discussed as part of the literature cited in this paper, and is certainly not common within the tourism literature (with the exception of adventure tourism studies). Horton (2007) argues that fear in cycling has been under-analysed, and there is a need for greater understanding of fear in cycling. In his account of fear in cycling, he raises several points that are (subconsciously) reflected within my own experiences. Horton (2007) argues for a socially constructed fear of cycling, reinforced through social relations and warning to "take care" or to avoid engaging in such "risky" behaviour. Indeed, he argues that to ignore this safety advice is to transgress the new moral consensus, and reinforce the cyclist's status as "strange", "other" and stigmatised. Certainly after my own experience, I was shocked to find that I was considered to blame for engaging in such a "risky" behaviour, and being on the road in the first place, thereby shaking my confidence even further and leading me to question the wisdom of road cycling.

To further explore this finding within the wider social context of the ride, I searched for media reports of cycling in Cairns during the period between my own accident (May 2009) and the time of writing this manuscript (September 2011). A total of 18 reports of cycling in the Cairns region appeared in the Cairns Post during that 29 month period. These included four deaths on the local roads, one that reported two serious injuries (both of whom were later to become prominent figures in the Cardiac Challenge, and one of whom is a major sponsor of the event), five articles considering the poor safety standards of local roads for bicycles, 
two articles covering memorial rides for those killed in traffic incidents), two on the number of cycling accidents on the road ("Cycling injuries soar in Cairns" Cairns Post, December 17, 2009; "Five cyclists a week end up in Hospital" Cairns Post, July 23, 2010), two concerning the risky behaviour of cyclists on the road (e.g. "No hands, helmet or brains" Cairns Post, October 31,2009) and finally four with positive messages for rider safety and a call to motorists to "share the road" with cyclists (one in 2009, one in 2010, and two in 2011). The overall message of the articles could justifiably be interpreted as a warning cyclists were not welcome on Cairns roads.

Thus, the decision to join the Cardiac Challenge not only provided the opportunity to regain my fitness and confidence around cycling but would also re-establish a discourse around the legitimacy of cycling as a form of soft mobility. Horton (2007) also suggests that cyclists who do not stick to the margins but choose to "centre" themselves appear threatening and unsettling, and may even be demonised. For riders in the lead packs, as well as the organisers of the ride, cycling played a central role in their lives (using Ritchie et al.'s, 2010, study of enduring involvement); these riders already had adopted a central role, blazing a path for the rest of us to follow and providing strategies to cope with the stigmatisation of cyclists. Being able to capture such a personal element that would arguably not have been revealed through questionnaires or interviews, brings us to a discussion of the findings.

\section{CONCLUSION}

In using the analytic autoethnographic approach I hope to have provided the reader with a "certain transparency" that enables the reader to "get a sense of the meaning structures of the experience being described" (Jamal \& Hollinshead, 2001, p.77). The aim of this paper was to examine both the manifest (tip of the iceberg) and latent (below the waterline) aspects of the

experience, which Holbrook and Hirschman (1982) argue are "more subconscious and private in nature" as they often "mask[s] embarrassing or socially sensitive ideas and perceptions" or alternatively are "anxiety provoking [in] nature [which] encourages disguise at a subconscious level” (p.136). By adopting an autoethnographic approach I sought to retrieve and report these aspects of the experience, using "sufficiently indirect methods [...] to overcome sensitivity barriers" (Holbrook \& Hirschman, 1982, p.136).

Furthermore, the findings raise questions about how we might understand the unspoken facets of the tourism experience. In this case, fear and anxiety regarding cycling in traffic 
were a major push factor to participate in the event. Such topics are not easy to discuss with external researchers, or to capture in their entirety through prescriptive research methods. The issues around social representation of cyclists might also affect how cyclists choose to disclose their thoughts and feelings around cycling. However, as these issues are raised and the discourse around cycling continues to grow, we begin to see a change in how the cyclist is perceived. Indeed, Horton (2007, p146) concludes that the "cycling stranger embodies the possibility of a different social order". I suggest that autoethnography is one method that allows these nuances to be captured, furthering our knowledge of the field without causing undue ethical harm to other event participants that would almost certainly arise as a result of researchers venturing into the realm of the subconscious, almost approaching the role of lay therapist.

I argue that accessing this knowledge through methods such as autoethnography has both intrinsic value in understanding the experiences and adds to the existing literature on market segments, infrastructure needs, planning and management, and social, environmental and economic impact studies of cycling tourism. The use of autoethnography also allows that "certain transparency", that allows others to get a sense of meaning structures of the experience being described (Jamal \& Hollinshead, 2001, p.77) and capture that part of the experience that is dynamic and elusive of positivist research (Jamal \& Hollinshead, 2001, p.67). It is heavily dependent on self-reflection from the researcher, who must be prepared to reveal and examine uncomfortable feelings and events (such as the fear of cycling in my case). It also relies on the unfolding narrative to help us understand the world around us. Flyvbjerg (2001, p.84) argues that "good narratives typically approach the complexities and contradictions of real life" and to simplify them compromises the value that narratives offer us in understanding the world around us. This perhaps reflects the call for caution raised by Weed $(2006,2011)$ and Shipway (2010) that much of sport tourism experiences may not be apparent using the more scientific approaches, and would benefit from a greater diversity of methodologies.

Additionally, this study responds to a call for more work into events at the boundary of charity, sports and tourism (Lamont, 2009), embodied research (Jamal \& Hollinshead, 2001; Phillimore \& Goodson, 2004; Swain, 2004) as well as capturing those aspects of the "canvas of tourism truth" that are largely unchartered. Indeed a number of questions might ensue from this research. For example, how might one capture (and cater for) the heterogeneity of participants and their experiences. Lumsdon (2000) comments that the appeal of cycle 
tourism lies in providing a tourism experience which visitors desire such as offering a challenge or an overall feeling of relaxation and well-being (p.372). Whilst perhaps selfevident in theory, the findings of this study demonstrate that this might be harder to achieve in practice, given the heterogeneity of the market and the participants' experiences (as I observed in the last diary excerpt presented here).

In summary, this paper has provided some insights into one event that occurs at the boundaries of cycling tourism, sports and charity events. It responds to a call for more research in this area, whilst advocating for an understanding of the nuances that permeate participants' experiences of such events. Failure to recognize and acknowledge these nuances may lead to misleading managerial suggestions, poor policy design, and unsuccessful new initiatives. Despite common misgivings regarding the validity and generalisability of autoethnographic studies, it is precisely the subjectivity and transparency of this approach that allow further explorations of the nuances in multi-day charity cycling events.

\section{References:}

Allen-Collinson, J. \& Hockey, J. (2010). Feeling the way: Notes toward a haptic phenomenology of distance running and scuba diving. International Review for the Sociology of Sport 46(3), 330-345.

Anderson, L. (2006). Analytic authoethnography. Journal of Contemporary Ethnography, 35(4): 373-395.

Beard, J.G. \& Ragheb, M.G. (1983). Measuring leisure motivation. Journal of Leisure Research, 15(3), 219-228.

Belhassen, Y. \& Caton, K. (2009). Advancing understanding: A linguistic approach to epistemology. Annals of Tourism Research, 36, 335-352.

Belk, R. \& Wallendorf, M. (1990). The sacred meanings of money. Journal of Economic Psychology, 11, 35-67.

Berger, I.E., Greenspan, I. \& Kohn, D. (2007). Identity, re-creation through recreation: The case of the Alyn Charity Bike Ride. Canadian Journal of Jewish Studies, 15, 1-36.

Botterill, D. (2003). An autoethnographic narrative on tourism research epistemologies. Loisir et Society, 26(1): 97-110.

Boylorn, R.M. (2008): As Seen On TV: An Autoethnographic Reflection on Race and Reality Television. Critical Studies in Media Communication, 25(4), 413-433

Buckley, R. (2010). Adventure tourism management. Oxford: Elsevier.

Chen, P.J. (2006). The attributes, consequences, and values associated with event sport tourists' behaviour: a means-end chain approach. Event Management 10, 1-22.

Coffey, P. (1999). The ethnographic self. London: Sage. 
Collinson, J.A. (2008). Running the routes together: Co-running and knowledge in action. Journal of Contemporary Ethnography, 37(1). 38-61.

Deetz, S. (1996). Describing differences in approaches to organisation science: rethinking Burrell and Morgan and their legacy. Organisation Science, 7(2), 191-207.

Dickinson, J.E., \& Robbins, D. (2009). Other people, other times and special places: A social representations perspective of cycling in a tourism destination. Tourism and Hospitality Planning \& Development, 6(1), 69-85.

Dickinson, J. Lumsdon, L. \& Robbins, D. (2011). Slow travel: issues for tourism and climate change. Journal of Sustainable Tourism, 19(3), 281-300.

Downward, P. \& Lumsdon, L. (2001). The development of recreational cycle routes: an evaluation of use needs. Managing Leisure, 6, 50-60.

Ellis, C. (2004). The ethnographic I: a methodological novel about autoethnography. Oxford: AltaMira Press.

Faullant, R., Matzler, K. \& Mooradian, T. (2011). Personality, basic emotions and satisfaction: primary emotions in the mountaineering experience. Tourism Management $32,1423-1430$.

Faulks, P., Ritchie, B.W., Brown, G. \& Beeton, S. (2008). Cycle Tourism and South Australia Destination Marketing: an exploratory study. Gold Coast: Sustainable Tourism Cooperative Research Centre.

Faulks, P., Ritchie, B.W., \& Fluker, M. (2007). Cycle Tourism in Australia: an investigation into its size and scope. Gold Coast: Sustainable Tourism Cooperative Research Centre.

Fleming, C. \& Fullagar, S. (2007). Reflexive Methodologies: an autoethnography of the gendered performance of sport/management. Annals of Leisure Research 13, 238-256.

Flyvbjerg, C. (2001). Making social science matter: why social inquiry fails and how it can succeed again. Cambridge: Cambridge University Press.

Garrard, J., Greaves, S. \& Ellison, A. (2010). Cycling injuries in Australia: Road safety's blind spot? Journal of the Australian College of Road Safety, 21(3), 37-43.

Getz, D. (2008). Event Tourism: Definition, evolution and research. Tourism Management 29, 403-428.

Gibson, H. (2004). Moving beyond the "what is and who" of sport tourism to understand "why". Journal of Sport Tourism 9(3), 247-265.

Gibson, C. \& Kong, L. (2005). Cultural economy: a critical review. Progress in Human Geography, 29(5), 541-561

Goodwin, H., McCombes, L. \& Eckardt, C. (2009). Advances in Travel Philanthropy:Raising money through the travel and tourism industry for charitable Purposes. WTM Responsible Tourism Day (Report 2). Retrieved from $w w w . i c r t o u r i s m . o r g / d o c u m e n t s / 2 \_n o v \_w t m \_t p \_f i n a l \_r e p o r t . p d f$.

Henderson, K. A. (1981). Motivations and perceptions of volunteerism as a leisure activity. Journal of Leisure Research, 13(3), 260-274.

Holbrook, M.B. \& Hirschman, E.C. (1982). The Experiential Aspects of Consumption: Consumer Fantasies, Feelings and Fun. Journal of Consumer Research 9, 132-140. 
Holloway, I., Brown, L. \& Shipway, R. (2010). Meaning not measurement: using ethnography to bring a deeper understanding to the participant experience of festivals and events. International Journal of Event and Festival Management 1(1), 74-85.

Holt, N. (2003). Representation, legitimation and autoethnography: an autoethnographic writing story. International Journal of Qualitative Methods, 2(1), 1828.

Horton, D. (2007). Fear of Cycling. In D. Horton, P. Rosen \& P. Cox (eds) Cycling and Society, Aldershot: Ashgate. pp.132-152

Iso-Ahola, S. E. (1980). The Social Psychology of Leisure and Recreation. Dubuque, IA: Brown.

Jacobsen, P.L. (2003). Safety in numbers: more walkers and bicyclists, safer walking and bicycling. Injury Prevention, 9, 205-209.

Jamal, T. \& Hollinshead, K. (2001). Tourism and the forbidden zone: the underserved power of qualitative research. Tourism Management, 22, 63-82.

Jennings, G., Kachel, U., Kensbock, S. \& Smith, M. (2009). Tourism and hospitality research students' experiences: How to achieve quality, inclusivity, and belongingness. Journal of Hospitality and Tourism Management, 16, 139-147.

Klein, K. (1998). Make fundraising your career. Grassroots Fundraising Journal, 17(1), 3-5.

Lamont, M. (2009). Reinventing the Wheel: a definitional discussion of bicycle tourism. Journal of Sport and Tourism, 14(1), 5-23.

Leonard, S., Spotswood, F. \& Tapp, A. (2011). Overcoming the self-image incongruency of non-cyclists. Journal of Social Marketing, 2(1), 23-36.

Lumsdon, L. (2000). Transport and tourism: cycle tourism - a model for sustainable development? Journal of Sustainable Development, 8(5), 361-377.

Lyng, S. (1990). Edgework: a social psychological analysis of voluntary risk taking. American Journal of Sociology, 95, 851-856.

Lyons, K. (2007). Innovations in volunteer tourism: A case study of fundraising adventure tours. BEST Education Network Think Tank VII Innovations for Sustainable Tourism. Northern Arizona State University.

Lyons, K. \& Wearing, S. (2008). All for a good cause? The blurred boundaries between volunteering and tourism. In Lyons, K. \& Wearing, S. (2008) Journeys of Discovery in Volunteer Tourism. CABI International: Wallingford.

Maslow, A.H. (1977). Religions, values and peak experiences. Harmondsworth: Penguin.

McIntyre, N. (1989). The personal meaning of participation: enduring involvement. Journal of Leisure Research, 1(3), 33-42.

Merriam, S. (2002). Qualitative research in practice: examples for discussion and analysis. San Francisco, Jossey-Bass.

Muzaini, H. (2006). Backpacking southeast Asia: strategies of looking local. Annals of Tourism Research, 33(1), 144-161.

Noy, C. (2007). The Language(s) of the tourist experience: an autoethnography of the poetic tourist. In Ateljevic, I., Pritchard, A. \& Morgan, N. (eds.). The Critical Turn in Tourism Studies: Innovative Research Methodologies. London: Elsevier, pp. 349-370. 
Parker, S. (1992). Volunteering as serious leisure. Journal of Applied Recreation Research, 17(1), 1-11.

Pearce, J. L. (1993). Volunteers: the organisational behaviour of unpaid workers. London, Rutledge.

Pearce, P. L. \& U. Lee (2005). Developing the travel career approach to tourist motivation. Journal of Travel Research, 43, 226-237.

Phillimore, J., \& Goodson, L. (2004). Progress in qualitative research in tourism. In J. Phillimore \& L. Goodson (Eds.), Qualitative Research in Tourism (pp. 4-29). London: Routledge.

Pritchard, A., Morgan, N. \& Ateljevic, I. (2011). Hopeful tourism, a new transformative perspective. Annals of Tourism Research doi:10.1016/j.annals.2011.01.004

Ren, C., Pritchard, A. \& Morgan, N. (2010). Constructing tourism research; A critical enquiry. Annals of Tourism Research, 37, 885-904.

Richards, G. (2006). Developing creativity in tourist experiences: a solution to the serial reproduction of culture? Tourism Management, 27, 1209-1223.

Richards, G. (2010). Creative tourism and cultural events. Paper presented at the 2nd Forum on UNESCO Creative Cities Network Icheon, Republic of Korea, 21 October 2010.

Richardson, L. (1994). Writing a method of inquiry. In Denzin, N.K. \& Lincoln, Y.S. (Eds.) Handbook of Qualitative Research (pp.516-529). London; Sage Publications.

Rissel, C., Bongfiglioli, C., Emilsen, A. \& Smith, B. (2010). Representations of cycling in metropolitan newspapers - changes over time and differences between Sydney and Melbourne, Australia. BMC Public Health, 10,371-379.

Ritchie, B.W. (1998). Bicycle tourism in the South Island of New Zealand: planning and management issues. Tourism Management, 19(6), 567-582.

Ritchie, B.W., Tkaczynski, A. \& Faulks, P. (2010). Understanding the motivation and travel behaviour of Cycle Tourists using Involvement Profiles. Journal of Travel and tourism Marketing, 27, 409-425.

Robinson, T. \& Gammon, S. (2004). A question of primacy and secondary motives: revisiting and applying the sport tourism framework. Journal of Sport Tourism 9(3), 221-233.

Scarles, C. (2010). Where Worlds Fail, Visuals Ignite: opportunities for visual autoethnography in tourism research. Annals of Tourism Research 37(4), 905-926.

Shipway, R. (2010). On the Run: Perspectives on Long Distance Running (Unpublished Doctoral Thesis). Bournemouth University, UK.

Shipway, R. \& Jones, I. (2007). Running away from home: understanding visitor experiences and behaviour at sport tourism events. International Journal of Tourism Research 9, 373-383.

Smith, G. (2004). Asking properly: the art of creative fundraising. Kerrnarquer, The White Lion Press Limited.

Snelgrove, R. \& Wood, L. (2010). Attracting and Leveraging Visitors at a Charity Cycling Event. Journal of Sport and Tourism 15(4), 269-285.

Sparkes, A.C. (2000). Autoethnography and narratives of self: Reflections of criteria in action. Sociology of Sport Journal, 17, 21-43. 
Sparkes, A.C. (2002). Telling tales in sport and physical activity; a qualitative journey. Human Kinetics: South Australia.

Stebbins, R. A. (1982). Serious leisure: a conceptual statement. Pacific Sociological Review, 25, 251-272.

Standeven, J. \& DeKnop, P. (1999). Sport Tourism. Champaign, Il. Human Kinetics.

Swain, M. (2004). (Dis)embodied experience and power dynamics in tourism research. In Qualitative Research in Tourism: Ontologies, Epistemologies and Methodologies, L. Goodson and J. Phillimore, eds., pp. 102-188. London: Routledge.

Tajfel, H., \& Turner, J. C. (1986). The social identity theory of intergroup behaviour. In S. Worchel \& W. G. Austin (Eds.), Psychology of intergroup relations (pp. 7-24). Chicago, IL: Nelson-Hall.

Tolich, M. (2010). A critique of current practice: ten foundational guidelines for autoethnographers. Qualitative Health Research 20(12), 1599-1610.

Tribe, J. (2006). The truth about tourism. Annals of Tourism Research, 33(2), 360-381.

Weed, M. (2006). Sports Tourism Research 2000-2004: A systemic review of knowledge and a meta-evaluation of methods. Journal of Sport \& Tourism 11(1), 5-30.

Won, D., Park, M., Lee, K.Y. \& Chung, J. (2011). Factors affecting participating in charity sport events involving a low intensive physical activity. International Journal of Leisure and Tourism Marketing 2(3), 248-257. 